\title{
MUSICAL CREATIVITY - CONSTITUTIVE ELEMENT OR PRODUCT OF MUSICAL TALENT DEVELOPMENT
}

\author{
UDC 37.036:78-053.5\%.6
}

\author{
Igor Nikolić, Slobodan Kodela \\ University of Niš, Faculty of Arts, Serbia
}

\begin{abstract}
Bearing in mind various positions of creativity in modern conceptions of giftedness, the study examines the role this phenomenon plays in development and manifesting of musical talent. The complexity of defining musical creativity is indicated by age specifics (i.e. difference between manifesting free musical expression by children and "true" creativity of adults), but also by attitudes of authors associating creativity exclusively to productive forms of expressing musical talent. The study presents some of the possibilities of evaluating/measuring musical creativity and importance of its encouraging at various ages and various educational contexts. Conclusion is that musical creativity at childhood age may represent a significant indicator of musical talent, but not necessarily a characteristic of talented children. On the other hand, valuable creative musical products can most often be expected only at a later age, as result of years of stimulating talent, developing of musical skills and specific musical-theoretical knowledge.
\end{abstract}

Key words: creativity, musical creativity, giftedness, musical talent, music teaching

Last decades have been dominated by great interest in gifted and talented people. This is confirmed by forming of new conceptions and models, which main goal is identification of gifted and talented individuals and stimulation of their potentials through organizing of various educational programmes. While majority of authors of these conceptions agree as to importance of (high) abilities as factors of giftedness (e.g. Gagné, 2008; Heller, 1991; McPherson \& Williamon, 2006; Persson, 2009; Renzulli, 2005; Sternberg, 2005; VanTassel-Baska, 2005), we may notice that attitude as to the role of creativity differ considerably. This leads to the conclusion that there is no consensus regarding nature and importance of this phenomenon.

Certain authors consider creativity as compulsory element of giftedness. Renzulli (2005) sees giftedness as interaction of above-average ability, creativity and task commitment,

Received October 6, 2016 / Accepted November 1, 2016

Corresponding author: Igor Nikolić

University of Niš, Faculty of Arts, Niš, Republic of Serbia

E-mail: igornik.fu@gmail.com 
whereas the WICS model (Sternberg, 2003; 2005) implies synthesis of intelligence, creativity and wisdom as condition to achievement. Tannenbaum (1986) observes creativity not only as component of giftedness, but also as an integral part of all the constituent factors of giftedness. Albert \& Runco (1986, by Maksić, 1993) advocate the standpoint that intelligence and creative behaviour should not be taken as different and independent elements, while Runco (2005) considers children and adults to possess the same creative potential. According to Gagné (2008), creative ability is a form of giftedness, that is, of natural abilities, and according to Heller (1991) one of the talent factors (predictors). On the other hand, VanTassel-Baska (2005) claims that creativity should not be observed as part of giftedness; the measure of creativity, in her opinion, is „unattainable“ in the process of identification. Feldhusen, similarly, observes creativity only as final product of giftedness and states that ,measuring of creative capacity [...] represents a problematic psychometric value“ and can „scarcely help identify giftedness“ (Feldhusen, 1986, by Maksić 1993, 19). Conflicting attitudes are found in local authors. While Avramović and Vujačić $(2009,880)$ consider that giftedness includes intelligence and creativity, Altaras claims that ,supreme creativity and expertise [...] represent possible outcome rather than valid operationalization of giftedness“" (Altaras 2006, 79-80).

However, researchers strive to define more precisely what is to be regarded as creativity and creative products. According to broadly accepted definition, creativity denotes ,the ability to create a work that is extraordinary [...] and appropriate“ (Sternberg \& Lubart 1999, 3). Componental theory of creativity (Amabile 1983; 1996 by Renzulli 2005, 259) includes three groups of factors: (1) skills relevant to domain (knowledge, technical skills within the domain, talents), (2) skills relevant to creativity (cognitive styles, work styles, heuristics) and (3) motivation for solving a specific task. According to other findings, creativity consists of general ability, set of domain-specific abilities and abilities required to solve an actual task (Lubart \& Gugnard 2004 by Persson 2009, 731). Given definitions therefore point to the necessity of possessing a certain degree of abilities and skills for the creativity to be manifested.

Maksić determines creativity in three ways - as ,quality of an individual (personality), characteristics of behaviour, or marks of certain achievements and products“" (Maksić, 1993 by Avramović and Vujačić 2009, 880). Following this position, in music we could distinguish creative individuals, creative behavours and creative musical products. Another type of distinction is made by Csikszentmihalyi (1996 by Renzulli 2005, 254). He primarily distinguishes persons with ,creative thoughts“", who could (unless they convert their thoughts into a significant product) rather be named brilliant then creative. Another meaning of the term creativity refers to ,personally creative“ individuals, i.e. individuals whose products and discoveries are significant to themselves, but not to others. Third type denotes person creative in the true meaning of the word, namely, persons considerably affecting the progress of culture. Csikszentmihalyi emphasizes that the given difference is not a matter of grading, but of different forms of creativity.

Supreme levels of creativity are often described by term ,genius“. M. Vujaklija closely associates genius as „extraordinary giftedness“ to elements of creativity and describes it as „great creative spiritual force“ that is inherent and is expressed as original ability of insight (intuition), combining (fantasy) and presentation“ (Vujaklija 1980, 168). Feldman and Benjamin denote by creativity the creation of new forms or new interpretation of the existing ones, while genius refers to changes reorganizing the complete area (Feldman \& Benjamin 
1986 by Maksić 1993, 28). Leman, Sloboda and Woody (Leman et al. 2012, 151) attribute genius to the best known of presons achieving mastery and perfection in their domain, i.e. those the works of whom receive „eternal glorification“.

Given the nature and modes of manifesting music as art, creativity is logically percieved as its integral part. The fact is that even very young children manifest certain forms of musical creativity, varying melodies they have heard or creating new ones. However, spontaneous musical expression by children cannot be considered as „true“ creativity, as many authors are pointing out. According to Winner and Martino, children manifest creativity of lower order, so called little-c creativity (Winner \& Martino 2000, 95), by resolving musical problems in (according to them) unconventional manners. On the other hand, ,true“ creativity (Big-C creativity) denotes change in domain, and requires at least 10 years of work in the domain. According to this definition, therefore, we cannot consider children as truly creative.

Winner and Martino hereby open the issue of relation between creativity and age. They emphasize the difference in skills required for an individual to be marked as extremely advanced (at a younger age) or truly creative. As by true creativity they denote impact over domain, Winner and Martino attribute these differences to personal factors: creative individuals are restless, rebellious, in constant desire to show something new (Winner \& Martino 2000, 107). Csikszentmihalyi also thinks that children cannot be associated to true creativity (Csikszentmihalyi 1996 by Zimmerman 2004, xxxi). Leman and associates explain that children's generativity (creativity, creation) appears with the purpose of learning and mastering the domain, therefore not primarily with the ,urge" to produce or create a work (Leman et al. 2012, 167). Given the above, we can conclude with certainty that there is a difference between creativity of children and adults. Still, is creative potential achieved by maturing? Let us recall the standpoint of Runco (2005) that creative potential is present both in children and adults, in the same form, while accomplishing of the potential is manifested in various qualities due to accumulated knowledge. This again brings us to the claim that manifesting of „true“ creativity requires developed abilities, as well as foundation of knowledge and skills within the specific domain. This is emphasized by musical pedagogues: Kršić, for example, considers the sound system (linear and vertical) to be the foundation for independent creation of music, set in the ,,auditory sphere of a musician“ and acting in interaction with the ,already learnt, consciously acquired knowledge" (Kršić 2001, 126). Musical experience is precondition to musical creativity in broader sense, strongly pointed by Leman and associates: „Only if we know what really exists can we intentionally invent something new, or at least recognize that it has just happened to us" (Leman et al. 2012, 163).

Although manifesting of musical creativity requires mastery of specific musical abilities, it seems that general (intellectual) ability does not fundamentally affect the creative accomplishments. While Renzulli thinks that creative accomplishment requires a high (but not an extraordinary one) level of intelligence (Renzulli 2005, 262), other research question relation between the two factors (comp. to Gojkov 2008, 89). In his research Barron has discovered a zero or negative correlation between degree of intelligence and estimated quality of work by painter, sculptor or designer (Barron 1968 by Renzulli 2005, 262). Studying the relation between intelligence and creativity, Sternberg differentiates the categories by linking intelligence to acceptance of social norms, and creativity to confrontation of an individual to these norms and introduction 
(proposal) of new ones. He also states that a person has to be intelligent to be creative, while creativity is not the quality of all intelligent people" (Sternberg 2001 by Zimmerman 2004, xxxi).

Haroutounian (2008) provides a somewhat broader definition of musical creativity, including improvisation and composing, but also creative listening and creative interpretation. As musical creativity is most easily recognized in composing and improvisation actions, here we shall explain other given forms of creativity. The author associates a creative listener, as form of „hidden talent“ (Haroutounian 2008, 12) to a student with ,sharp“ musical ear, who, nevertheless, fails to manifest his talent (often due to technical limitations) in the domain of performance. We assume that children with such creativity can develop into quality musical critics or musicologists. Creativity is also manifested in musical perormance, which implies giving a personal touch to the composer's idea, naturally, with respect of stilistic limitations. We need to mention that, instead of the term creativity, Haroutounian uses the term creative interpretation in broader sense, in order to include all the named forms of manifesting musical creativity composing and improvising, creative listening and creative performing of music. However, not all authors agree that creativity equally involves all forms of manifesting musical talent. Persson $(2009 ; 2011)$, presenting three basic domains of musical talent (voice performance, instrument performance and the domain including composing, conducting and arranging), associates true creativity exclusively to the third mentioned (productive) domain. He considers performers of west-European musical tradition to have very limited opportunities to be creative, being expected to follow fixed performing norms (Persson 2011, 11). Similarly, McPherson and Williamon (2006) believe creativity to be the principal factor of composing and improvising, whereas it need not be considered a crucial component in the domain of classical performance.

If we observe creativity as one of the elements of musical talent, recognizing talented students would require a form of evaluation or measuring of creativity. It is the evaluation of creativity itself (even at today's degree of scientific development) that is being described as debatable, relative and subjective category. Renzulli (2005), although attempting to emphasize importance of all clusters within his conception, admits that creativity cannot be objectively evaluated, such as abilities. This is affected by another problem of more general character. Namely, a work can be regarded as an important creative achievement if such conclusion is based on evaluation of an elite group of people at a given moment in history (Csikszentmihalyi 1999 by Gojkov 2008, 39). However, relativity of such claim is evident, which is ascertained by a large number of works that we consider extraordinary, while at the moment of their creation they were not estimated as valuable; on the other hand, initially accepted importance of a creative work or idea can in time be considerably diminished. Difficulties in measuring creativity certainly do not represent a reason to desist from such process. In practice tests are evident for measuring of general creativity where Torrance test of creative thinking is often being applied. It, however, has slightly lower quotient of reliability and requires a „trained evaluator with experience“ (Maksić 1993, 48). More importantly, tests of general creativity are not suitable for measuring creativity in musical or artistic domain (Haroutounian 2008, 13) and they can predict more successfully creative achievements in writing, science or medicine, relative to that in music or visual arts (Torrance 1963 by Zimmerman 2004, xxxi). 
Significant attempts of measuring creativity in music have been made by Webster (1994) and Wang (1985). The instrument of P. Webster, Measure of Creative Thinking in Music, is intended for children from 6 to 10 years of age, and includes individual measurement (20-25 minutes per examinee). It consists of 10 tasks divided into three stages - discovering, application and synthesis - where children are asked to produce different tones on the piano, by wooden blocks or voice. Entire process is recorded by a video camera and subsequently evaluated. The evaluation involves two „objective“ factors - extensiveness (amount of time consumed in individual creative tasks) and flexibility (use of parameters such as pitch, tempo and dynamics), but also two factors liable to subjective evaluation - originality (uncommon and unique reply) and musial syntax (logical and meaningful answer). For this reason Webster recommends that the evaluation should be performed by a group of professionals. We should also consider the time consumption, given that evaluation of answers requires 40-60 minutes per examinee. Instrument of the author S. Wang, Measures of Creativity in Sound and Music, is similar in construction to Webster's. It is intended for the children from 4 to 8 years of age, and requires individual realization (20-30 minutes per child). This instrument, through four activity groups, is used to evaluate fluency and imagination of children through playing different instruments and expressing through movements. Analysis of the named measuring instruments leads to conclusion that they still rely on subjective evaluations of professionals. Given the compexity of phenomenon of musical creativity, perhaps the only true way of its evaluation lies in the hands and experience of musical pedagogues. Musical creativity can be heard and noticed, although for the time being cannot be fully explained. In this respect, Ryan and Brown conclude their work with question: „Do we need to measure something that is so elusive and possibly immeasurable?" (Ryan \& Brown 2012, 117-118).

Regardless of the named difficulties in defining and evaluating of creativity, a talented musician is certainly expected to provide at some point a form of creative (musical) contribution. For this reason, the necessity is emphasized of encouraging musical creativity even from an early age, both in general educational and schools with professional musical orientation. Creative aspects of teaching are not a goal themselves, but are a positive influence on progress of musicality, also on development of individual musical abilities. In this period teachers are imposed with an important task of forming the spontaneous musical expressing of children progressively to conscious forms of creating. An interesting fact on stimulating creativity at an early age is provided by experience of the author Haroutounian, who developed Explorations In Music, a theory and composition curriculum. Namely, numerous teachers have asked why composition (creative) processes have found place in the first book already, when at that age students are still not familiar with notation. On the other hand, children did not ask such questions, but simply engaged in creative work (Haroutounian 2008, 11). The fact that creativity in children is closely related to emotions implies the importance of creating certain conditions (work atmosphere). Even Hallman has, in this respect, studying relevant sources, named factors to be avoided in order to stimulate creativity (Hallman 1973 by Grandić \& Letić 2009, 239-240). Some of these factors are authoritarian environment, exaggerrated rewarding, excessive insistance on precision, over-frequent emphasis on success, but also negative attitude to different personalities (given that students behaving outside of "traditional norms“ can often be creative). 
Having in mind the specialized music education and solfeggio classes, it is evident that musical creation and improvisation may considerably stimulate musical skills, and, more generally, development of musical talent. Children's musical creation may evolve in two directions: „oral, direct path and, after literacy, by written, 'note' path“ (Radičeva 1997, 117). This means that creative processes may be initiated from the very beginning of musical teaching, even before young students learn musical symbols, when actions are based on melodies and motives with text. In the period of acquiring literacy the text gives way to note syllables, quite positively affecting association of picture and sound and development of musical thinking. Throughout entire music education different methodic actions can be used that are directed towards development of creative abilities, to gradually increase in complexity (Radičeva 2000; Kodela \& Nikolić 2014): exercises of asking and answering, finishing melodic and rhythmic flows, improvisation of melody to the given text that is subsequently connected to notes, creation of melody to the given rhythm, varying the melody, creation of melodic flow on the basis of harmonic pattern, etc. Certainly the highest achievement in creative work of teaching solfeggio represents impovisation in complete facture (improvising and singing of melodic-rhythmic context by solmization, along with creating and performing of harmonic accompaniment on instrument) the successful realization of which is expected only on highest levels of education - end of secondary music school and music studies. Significance of improvisation is reflected in the fact that it synthesizes many processes: ,,musical invention is remembered, it converts into note picture on the basis of consciousness of tone pitch and duration the subjects hears inside. Improvisations help in the most reliable way to develop musical thinking..." (Vasiljević 1985, 169).

It is evident that elements of creativity are predicted by the curriculum as early as in elementary music education. However, impressions from practice indicate the fact that creative processes in elementary and secondary music schools are not realized to sufficient extent, which should certainly be appealed to in expert circles. Authors of this study have asked the first year students in Solfeggio exercises to create a musical flow in relation to the given motive, and perform it by solmization. Still, a student, generally excellently intonating examples and writing down dictations, answered: „I don't know how to do that... solfeggio is not a creative subject... at least it has not been until now". So, we should make an endeavour to stimulate musical creativity in children and youths through interactive approach, starting from preschool institutions, through general music classes in school, to specialized music education at all levels, which can have positive effect on manifesting of musical potential and adequate directing of development of musical talent.

How, finally, should we understand musical creativity - as constituting element of musical talent without which it cannot develop and manifest, or as its possible product? Analysis of general conceptions of giftedness leads to the conclusion that creativity certainly represents a desirable outcome to years of encouraging a gifted individual. However, we should have in mind that certain domains imply creativity at almost all levels of development of a gifted person, while in other domains the „,criteria of success can mostly be satisfied by expertise“ (Altaras 2006, 57), for which reason creativity does not have to be considered a compulsory quality of gifted persons. In terms of musical talent, creative expression at early age certainly represents a significant diagnostic mark i.e. indicator, as through such activities pedagogues can spot musicality, musical abilities, motivation, musical-theoretical knowledge and other factors. Still, we cannot expect each 
child that we consider to be musically talented to be musically creative, as well. Standpoints in literature show that creativity is an important quality of only some of the forms of manifesting musical talent (Persson 2009; 2011; McPherson \& Williamon, 2006). For this reason, we may assume that even the children who do not stand out considerably in creative production, but are musically capable, motivated and physically predisposed, can become eminent musical performers. Besides, we must take into consideration that creative musical products may in true sense be expected only with adults, as outcome of years of stimulating talent, developing of musical skills and specific muisical-theoretical knowledge, whereas children, resolving problems in unusual, unconventional ways, display creativity of lower order, i.e. what Winner and Martino (2000) postulate as little-c creativity. In relation to the aforesaid, creativity at children's age shall be considered as significant indicator of musical talent, but not its constituting element, while ,true“ creativity as product of musical talent can most often be expected only at a later age.

\section{REFERENCES}

Avramović, Z. \& M. Vujačić. (2009). Odnos nastavnika prema darovitim učenicima. Pedagoška stvarnost, 55 $(9-10), 878-889$

Altaras, A. (2006). Darovitost i podbacivanje. Beograd, Pančevo: Institut za psihologiju, Društvo psihologa Srbije, „Mali Nemo“

Gagné, F. (2008). Building gifts into talents: Brief overview of the DMGT 2.0. [Online]. Available: http://nswagtc.org.au

Gojkov, G. (2008). Metodološki problemi istraživanja darovitosti. Vršac: Visoka škola strukovnih studija za obrazovanje vaspitača „Mihailo Palov“

Grandić, R. \& M. Letić. (2009). Stanje, problemi i potrebe u području brige o darovitim učenicima u našem obrazovnom sistemu. In G. Gojkov (Ed.), Daroviti i društvena elita - Zbornik radova 15. okruglog stola.Vršac. Visoka škola strukovnih studija za obrazovanje vaspitača, 232-243.

Haroutounian, J. (2008). Kindling the Spark: Recognizing and Developing Musical Talent. 10th Asia-Pacific Conference on Giftedness, Singapore. [Online]. Available: http://hkage.org.hk

Heller, K. A. (1991). The nature and development of giftedness: A longitudinal study. European Journal for High Ability, 2, 174-188.

Kodela, S. \& I. Nikolić. (2014). Metodski postupci usmereni ka podsticanju stvaralačkih sposobnosti u nastavi solfeđa. In Zbornik radova II i III sipmpozijuma kompozitora, muzikologa, etnomuzikologa i muzičkih teoretičara. Sokobanja: Heroes, 104-109.

Kršić-Sekulić, V. (2001). Pevanje - spontani izraz muzičke ideje na putu za stvaralačku interpretaciju. In V. Milanković (Ed.), Zbornik radova Trećeg pedagoškog foruma, Beograd, 124-133.

Leman, A., Dž. Sloboda \& R. Vudi. (2012). Psihologija za muzičare: razumevanje i sticanje veština. Novi Sad, Beograd: Psihopolis institut, Univerzitet umetnosti, Fakultet muzičke umetnosti

Maksić, S. (1993). Kako prepoznati darovitog učenika. Beograd: Institut za pedagoška istraživanja

McPherson, G. \& A. Williamon. (2006). Giftedness and talent. In G. McPherson (Ed), The Child As Musician: A Handbook of Musical Development. Oxford: Oxford University Press, 239-256.

Persson, R. (2009). The Elusive Muse: Understanding Musical Giftedness. In L. Shavinina (Ed), International Handbook on Giftedness. Berlin: Springer, 727-749.

Persson, R. (2011). The Multidimensional Model of Musical Giftedness (3MG): Breaking new ground in understanding musical talent and musical thinking. WCGTC Conference, Prague. [Online]. Available: http://hj.diva-portal.org/smash/get/diva2:431753/FULLTEXT01

Radičeva, D. (1997). Uvod u metodiku nastave solfeđa. Novi Sad: Akademija umetnosti

Radičeva, D. (2000). Metodika komplementarne nastave solfeđa i teorije muzike. Novi Sad, Cetinje: Akademija umetnosti, Muzička akademija 
Renzulli, J. S. (2005). The Three-Ring Conception of Giftedness: A Developmental Model for Promoting Creative Productivity. In R. Sternberg \& J. Davidson (Eds), Conceptions of Giftedness. New York: Cambridge University Press, 246-279.

Runco, M. (2005). Creative Giftedness. In R. Sternberg \& J. Davidson (Eds). Conceptions of Giftedness. New York: Cambridge University Press, 295-311.

Ryan, T. \& K. Brown. (2012). Musical Creativity: Measures and Learning. Journal of Elementary Education, 22 (2), 105-120.

Sternberg, R. J. (2003). Wisdom, intelligence, and creativity, synthesized. New York: Cambridge University Press

Sternberg, R. J. (2005). The WICS Model of Giftedness. In R. Sternberg \& J. Davidson (Eds). Conceptions of Giftedness. New York: Cambridge University Press, 327-342.

Sternberg, R. J. \& T. I. Lubart. (1999). Concept of creativity: Prospects and paradigms. In R. J. Sternberg (Ed.), Handbook on creativity. New York: Cambridge University Press, 3-15.

Tannenbaum, A. J. (1986). Giftedness: A psychosocial approach. In R. J. Sternberg \& J. E. Davidson (Eds.), Conceptions of giftedness. New York: Cambridge University Press. 21-52.

VanTassel-Baska, J. (2005). Domain-Specific Giftedness: Applications in School and Life. In R. Sternberg \& J. Davidson (Eds), Conceptions of Giftedness. New York: Cambridge University Press. 358-376.

Vasiljević, Z. (1985). Teorija ritma sa gledišta muzičke pismenosti. Beograd: Univerzitet umetnosti

Vujaklija, M. (1980). Leksikon stranih reči i izraza. Beograd: Prosveta

Wang, C. (1985). Measures of creativity in sound and music. Unpublished manuscript. [Online]. Available: http://www.uky.edu/ cecilia/MCSM/

Webster, P. (1994). Measure of Creative Thinking in Music (MCTM): Administrative Guidelines. [Online]. Available: http://online.uncg.edu

Winner, E. \& Martino, G. (2000). Giftedness in Non-Academic Domains: The Case of the Visual Arts and Music. In K. Heller, F. Mönks, R. Sternberg \& R. Subotnik (Eds), International Handbook of Giftedness and Talent, 2nd Edition. Oxford: Elsevier Science Ltd, Kidlington, 95-110.

Zimmerman, E. (2004). Introduction to Artistically and Musically Talented Students. In E. Zimmerman (Ed.), Artistically and Musically Talented Students. California: Corwin Press, xxiii-xxxiv.

\section{MUZIČKA KREATIVNOST - KONSTITUTIVNI ELEMENT ILI PRODUKT RAZVOJA MUZIČKOG TALENTA}

Imajući $u$ vidu različit položaj kreativnosti u savremenim koncepcijama darovitosti, rad proučava ulogu ovog fenomena u razvoju i manifestaciji muzičkog talenta. Na kompleksnost definisanja muzičke kreativnosti upućuju uzrasne specifičnosti (tj. razlike u ispoljavanju slobodnog muzičkog izražavanja dece $i$,prave“ kreativnosti odraslih), ali i stavovi autora prema kojima se kreativnost povezuje samo sa produktivnim vidovima ispoljavanja muzičkog talenta. U radu su prikazane neke od mogućnosti procene/merenja muzičke kreativnosti i značaj njenog podsticanja u različitim uzrastima i različitim obrazovnim kontekstima. Zaključeno je da muzička kreativnost na dečjem uzrastu može da predstavlja značajan indikator muzičkog talenta, ali ne i obaveznu karakteristiku talentovane dece. S druge strane, vredni kreativni muzički produkti najčešće se mogu očekivati tek na starijim uzrastima kao ishod dugogodišnjeg podsticanja talenta, razvoja muzičkih veština i specifičnih muzičko-teorijskih znanja.

Ključne reči: kreativnost, muzička kreativnost, darovitost, muzički talenat, muzička nastava 